\title{
The regulatory framework for investment: where are we headed?
}

\author{
Karl P. Sauvant \\ The Future of Foreign Direct Investment and the Multinational Enterprise \\ Research in Global Strategic Management, Volume 15, 407-433 \\ Copyright $(\underset{2}{2} 2011$ by Emerald Group Publishing Ltd
}

\begin{abstract}
Governments throughout the world have sought, and are seeking, to attract foreign direct investment and, for that purposed, have liberalized their national regulatory frameworks for FDI and established a strong international investment law regime. However, there are signs that, as a result of a number of important developments (which are being discussed in some detail in this chapter), governments are reevaluating their stance toward FDI, or at least certain types of it. This re-evaluation has found its expression in a number of regulatory changes that may eventually lead to a regime that balances the rights of investors and host countries in a manner that places more emphasis on maintaining policy space for host country governments while still protecting foreign investors.
\end{abstract}

As Yair Aharoni has pointed out, "globalization compels almost all firms to organize all value-added activities in a global manner". 2 Globalization has, in no small measure, been driven by foreign direct investment (FDI). While world FDI flows averaged US\$50 billion during the first half of the 1980s, they had reached US\$2.1 trillion in 2007 (before declining, I would say temporarily, to US\$1.1 trillion in 2009, on account of the financial crisis and recession) (table 1). ${ }^{3}$ These flows, undertaken by more than 80,000 multinational enterprises (MNEs), had accumulated to a stock of some US\$19 trillion in 2009. The FDI stock generated in this manner, via 800,000 plus foreign affiliates, produces estimated sales of goods and services of some US\$30 trillion, a figure that compares with world exports of US\$16 trillion (one third of which consists of intrafirm trade). These figures refer only to control exercised by parent companies through FDI. Control over firms abroad can, of course, also be exercised through various non-

\footnotetext{
${ }^{1}$ Founding Executive Director, Vale Columbia Center on Sustainable International Investment, a joint center of Columbia Law School and The Earth Institute at Columbia University, New York. This contribution draws partly on Karl P. Sauvant and Jose E. Alvarez, "Introduction: international investment law in transition", in Jose E. Alvarez and Karl P. Sauvant, with Kamil Ahmed and Gabriela del P. Vizcaino, eds., The Evolving International Investment Regime: Expectations, Realities, Options (New York: Oxford University Press, forthcoming 2011). I gratefully acknowledge helpful comments by Seev Hirsch, Ucheora Onwuamaegbu, Srilal Perera and Ravi Ramamurti, as well as the help of Wouter Schmit Jongbloed in the finalization of this manuscript.

${ }^{2}$ Yair Aharoni, "Reflections on multinational enterprises in a globally interdependent world economy", in Karl P. Sauvant and Geraldine McAllister, with Wolfgang A. Maschek, eds., Foreign Direct Investment from Emerging Markets: The Challenges Ahead (New York: Palgrave Macmillan), p. 42.

${ }^{3}$ UNCTAD, World Investment Report 2010: Investing in a Low-carbon Economy (Geneva: UNCTAD, 2010). This source, or earlier editions of it, has also been used for the following data, unless otherwise indicated.
} 
This chapter is ( $)$ Emerald Group Publishing and permission has been granted for this version to appear here (http://www.vcc.columbia.edu). Emerald does not grant permission for this chapter to be further copied/distributed or hosted elsewhere without the express permission from Emerald Group Publishing Limited.

equity forms (e.g., management contracts, technology and franchising agreements), in this manner (probably considerably ${ }^{4}$ ) expanding the scope of international production falling under the common governance of MNEs.

Table 1. Selected indicators of FDI and international production, 1990-2009

\begin{tabular}{|c|c|c|c|c|c|c|c|c|c|}
\hline \multirow[t]{2}{*}{ Item } & \multicolumn{4}{|c|}{$\begin{array}{l}\text { Value at current prices } \\
\text { [Billions of dollars) }\end{array}$} & \multicolumn{5}{|c|}{$\begin{array}{c}\text { Annual growth rate } \\
\text { (Per cent) }\end{array}$} \\
\hline & 1990 & 2005 & 2008 & 2009 & $1991-1995$ & $1996-2000$ & $2001-2005$ & 2008 & 2009 \\
\hline FOl in'gars & 208 & 986 & 1771 & 1114 & 225 & 400 & 52 & -157 & -371 \\
\hline FOI outflows & 241 & 893 & 1929 & 1101 & 16.8 & 36.1 & 8.2 & -149 & -42.8 \\
\hline FDI inward stock & 2082 & 11525 & 15491 & 17743 & 9.3 & 18.7 & 13.3 & .139 & 14.5 \\
\hline FOI outward stock & 2087 & 12417 & 16207 & 18932 & 11.9 & 18.4 & 14.5 & -16.1 & 17.1 \\
\hline Income on inward FDi & 74 & 791 & 1113 & 941 & 35.1 & 13.4 & 31.9 & .73 & -15.5 \\
\hline Income on cutward FDI & 120 & 902 & 1182 & $100 \mathrm{~B}$ & 20.2 & 10.3 & 31.3 & -7.7 & -14.8 \\
\hline Cross border MSAs a & 99 & 462 & 707 & 250 & 49.1 & 64.0 & 0.6 & .309 & -64.7 \\
\hline Sales of foreign affilistes. & 6026 & 21721 & $31068^{\circ}$ & $2929 \theta^{2}$ & 8.8 & 82 & 18.1 & $-45^{\circ}$ & $-57^{2}$ \\
\hline Gross product of foreign affliases & 1477 & 4327 & $6163^{1}$ & $5812^{\circ}$ & 6.8 & 70 & 13.9 & $-43^{1}$ & -57 \\
\hline Total assets of foreign affiliates & 5998 & 49252 & $71694^{r}$ & $77057^{i}$ & 19.7 & 19.0 & 20.9 & $-49^{f}$ & $7.5^{r}$ \\
\hline Exports of foreign affilstes & 1498 & 4319 & 66638 & $5188 \mathrm{~s}$ & 8.6 & 36 & 14.8 & 1548 & $-222 r$ \\
\hline $\begin{array}{l}\text { Employment by foreign affiliates } \\
\text { (thousands) }\end{array}$ & 24476 & 57799 & $78957^{3}$ & 79825 & 5.5 & 9.8 & 6.7 & $-3.7^{5}$ & 1.1 \\
\hline \multicolumn{10}{|l|}{ Memarandum } \\
\hline GOP (in curert: prioes) & 22121 & 46273 & 60766 & 05005 & 5.9 & 1.3 & 10.0 & 103 & -9.5 \\
\hline Gross foxed capital formation & 5099 & 9833 & 13822 & 12404 & 5.4 & 1.1 & 11.0 & 11.5 & -10.3 \\
\hline Royaltes and lioence foe receipts & 29 & 129 & 177 & & 14.6 & 8.1 & 14.6 & 86 & \\
\hline Exoorts of goods and services & 4414 & 12954 & 19 gse & 15716 & 7.9 & 3.7 & 14.8 & 15.4 & -21.4 \\
\hline
\end{tabular}

Source: UNCTAD, based on its FDI/TNC database (www.unctad.org/fdi statistics); UNCTAD, GlobStat; and IMF, International Financial Statistics, June 2010.

- Data are available only from 1987 onwards.

Data for 2007 and 2008 are based on the following regression result of sales against inward FDI stock (in millions of dollars) for the period $1980-2006$ sales $=144^{*} \cdot 6211+19343^{*}$ inward FDI stock.

Data for 2009 based on the observed year-over change of the sales of 3.659 TNCs' foreien operations between 2008 and 2009

Data for 2007 and 2008 are based on the following regression result of gross product against inward FDI stock (in millions of dollars) for the period 1982-2006: gross product $=566.7633+0.3658^{*}$ irward FDI stock.

- Decline in gross product of foreign afriliates assumed to be the same as the decline in sales.

Data for 2007 and 2008 are based on the following regression result of assets against inward FDI stock (in millions of dollars) for the period 1980-2006 assets $=-3387.7138+4.9069^{*}$ irward FDI stock

Data for 1995-1997 are based on the following regression result of exports of foreign affiliates against irrward FDI stock (in millions of dollars) for the period 1982-1994: exports $=139.1489+0.64^{*} 3^{*} \mathrm{FDI}$ irmard stock. For 1998-2009, the share of exports of foreign affiliates in world export in $1998(33.3 \%)$ was applied to obtain the values.

Based on the following regression result of employment (in thousands) against inward FDI stock (in millions of dollars) for the period 1980-2006: employment=17 642.5861+4.0071" inward FDI stock.

Data for 2009 based on the observed year-over change of the estimated employment of 3.659 TNCs' foreign operations between 2008 and 2009

Based on data from IMF. World Economic Outlook. April 2010.

Note: Not included in this table are the value of worldwide sales by foreign atfiliates associated with their parent firms through non-equity relationships and of the value of sales of the parent firms themselves. Worldwide sales, gross product, total assets, exports, and employment of foreign atfiliates are estima:ed by extrapolatirg the worldwide data of foreign aftiliates of TNCs trom Austria, Canada, the Czech Republic, Finland, France Germany, Italy, Japan, Luxembourg. Portugal, Sweden and the United States for sales: those from the Czech Republic. Portupal, Sweden and the United States for gross product: those from Austria. Germany. Japan and the United States for assets; those from Austria, the Czech Republic, Japan, Portugal, Sweder and the United States tor exports; and those from Austria, Germany, Japan. Switzerland and the United States for employment, on the basis of the shares of those countries in worldwide outward FDl stock

Source: UNCTAD, World Investment Report 2010: Investing in a Low-carbon Economy (Geneva: UNCTAD, 2010), p. 16.

Be that as it may, FDI has become more important than trade in delivering goods and services to foreign markets, integrating not only markets but also national production systems through an internal international division of labor of MNEs. This creates an integrated international production system - the productive core of the globalizing world economy. Moreover, since FDI consists of a bundle of tangible and intangible assets

\footnotetext{
${ }^{4}$ No systematic data exist on the importance of such non-equity forms; but in some industries (e.g., hotels), they are widespread.
} 
(including capital, employment, technology, skills, access to markets), it can play an important role in a country's development effort. ${ }^{5}$

At the same time, the landscape of the world FDI market is changing. In particular, firms headquartered in emerging markets are becoming important players, with, among them, state-controlled entities (especially state-owned enterprises and sovereign wealth funds (SWFs)) rising in importance. This, in turn, contributes to a reassessment of the costs and benefits of FDI in general, considering that such investment is, after all (from the perspective of governments), just a tool to advance their growth and development.

Given the role that FDI plays in the world economy and can play in national development, it is important to understand how this investment is regulated, both at the national and international levels. And since the international regulatory framework for investment has become an important parameter for national policy and rule making in this area, the following discussion focuses on the characteristics and development of the international investment regime.

\section{A. The national regulatory framework}

At the national level, many host countries, and especially emerging markets, ${ }^{6}$ have special laws and regulations in place that govern FDI, typically complemented by provisions in other laws and regulations (e.g., concerning taxation). The story of national FDI regulation, at least since the mid-1980s, is one of creating a favorable climate for this investment: countries have progressively liberalized the conditions for the entry of MNEs into their markets (by e.g. opening sectors to foreign investors); facilitated the operations of these enterprises (by e.g. abolishing performance requirements); and provided various protections to MNEs and their foreign affiliates (e.g., against arbitrary nationalizations). The data compiled by UNCTAD since 1992 document this story convincingly: out of a total of 2,748 regulatory FDI changes made by countries across the world during the

\footnotetext{
${ }^{5}$ See, e.g., UNCTAD, World Investment Report 1999: Foreign Direct Investment and the Challenge of Development (Geneva: UNCTAD, 1999); Theodore H. Moran, Harnessing Foreign Direct Investment for Development: Policies for Developed and Developing Countries (Washington: Center for Global Development, 2006); Theodore H. Moran, Foreign Direct Investment and Development: Launching a Second Generation of Policy Research. Avoiding the Mistakes of the First, Re-evaluating Policies for Development and Developing Countries (Washington: Peterson Institute for International Economics, forthcoming); John H. Dunning, "Re-evaluating the benefits of foreign direct investment", Transnational Corporations, vol. 2, no. 1 (1994), pp. 23-51; and John H. Dunning and Sarianna M. Lundan, Multinational Enterprises and the Global Economy (Cheltenham: Edward Elgar Publishing, 2008). However, it should be noted that national policies are important to maximize the positive effects of FDI and minimize any negative ones.

6 "Developed countries" are all members of the Organisation for Economic Co-operation and Development (OECD), minus Chile, Mexico, the Republic of Korea, and Turkey. "Emerging markets" are all economies that are not members of the OECD, plus Chile, Mexico, the Republic of Korea, and Turkey. "Developing countries" are all emerging markets that do not belong to the Commonwealth of Independent States and South-East Europe. See UNCTAD 2010, op. cit. for individual members of these groups.
} 
This chapter is $($ Emerald Group Publishing and permission has been granted for this version to appear here

(http://www.vcc.columbia.edu). Emerald does not grant permission for this chapter to be further copied/distributed or hosted

elsewhere without the express permission from Emerald Group Publishing Limited.

period 1992-2009, 89 percent were in the direction of making the investment climate more favorable to foreign investors (table 2).

Table 2. National regulatory changes, $1992-2009^{\mathrm{a}}$

\begin{tabular}{|c|c|c|c|c|c|c|c|c|c|c|c|c|c|c|c|c|c|}
\hline tem & 1 & & & 951 & 19961 & 19 & 19981 & 2 & 2 & 20012 & 20022 & 20032 & 2004 & 2005 & 200 & 0072008 & 2009 \\
\hline $\begin{array}{l}\text { Number of countries that } \\
\text { ntroduced changes }\end{array}$ & 43 & 56 & 49 & 63 & 66 & 76 & $\oplus 0$ & 85 & 70 & 71 & 72 & 82 & 103 & 92 & 91 & $58 \quad 54$ & 50 \\
\hline $\begin{array}{l}\text { Number of regulatory } \\
\text { changes }\end{array}$ & 77 & 100 & 110 & 112 & 114 & 150 & 145 & 139 & 150 & 207 & 246 & 242 & 270 & 203 & 177 & 106 & 102 \\
\hline Liberalizationipromation & 77 & 99 & 108 & 106 & 98 & 134 & 136 & 130 & 147 & 193 & 234 & 218 & 234 & 162 & 142 & 7483 & 71 \\
\hline Regulations/nestrictions & - & 1 & 2 & 6 & 16 & 16 & 9 & 9 & 3 & 14 & 12 & 24 & 36 & 41 & 35 & 2423 & 31 \\
\hline
\end{tabular}

Source: UNCTAD, World Investment Report 2010: Investing in a Low-carbon Economy (Geneva: UNCTAD, 2010), p. 77.

${ }^{a}$ Compared with reporting on these numbers in previous WIRs, the wording in the table has changed form "more favorable" to "liberalization/promotion" and from "less favorable" to "regulations/restrictions."

These regulatory changes have been accompanied by active efforts to attract FDI. Virtually all countries have an investment promotion agency at the national level, and many have such agencies also at the provincial and even city levels. There may be some 8,000 agencies in existence today worldwide, ${ }^{7}$ making the world market for FDI highly competitive. Typically, these agencies seek to attract as much FDI as possible to their shores, although an increasing number also have become more focused by targeting investors that can make a particular contribution to the host economy, in line with its overall development objectives. Financial, fiscal, regulatory, and other incentives are an important tool for this purpose, even though the effectiveness of such incentives is often questionable. $^{8}$

In addition, a rising number of home countries of MNEs (including virtually all developed countries, but also more and more emerging markets) facilitate the internationalization of their firms and even provide support to their MNEs to expand abroad, ${ }^{9}$ ranging from the provision of information about investment opportunities abroad, to the financing of feasibility studies, to the offering of insurance of investments against political risk. ${ }^{10}$ This reflects the expectation of governments that, to remain internationally competitive in an open world economy, their firms increasingly need to

\footnotetext{
${ }^{7}$ Millennium Cities Initiative and Vale Columbia Center on Sustainable International Investment, Handbook for Promoting Foreign Direct Investment in Medium-size, Low-budget Cities in Emerging Markets (New York: MCI and VCC, 2009), p. 1, available at www.vcc.columbia.edu. For a review of the performance of these agencies at the national level, see IFC, Global Investment Promotion Benchmarking 2009: Summary Report (Washington, DC: World Bank, 2009).

${ }^{8}$ See, UNCTAD, Incentives and Foreign Direct Investment (Geneva: UNCTAD, 1996).

${ }^{9}$ See, Peter J. Buckley, et al., "What can emerging markets learn from the outward direct investment policies of advanced countries?", in Sauvant and McAllister, with Maschek, op. cit., pp. 243-276, and Filip De Beule and Daniel Van Den Bulcke, "Changing policy regimes in outward foreign direct investment from emerging markets: from control to promotion", in ibid., pp. 277-304.

${ }^{10}$ On political risk, see MIGA, World Investment and Political Risk 2009 (Washington, DC: MIGA, 2009). For an example of how the institution of one country, the United States, has handled political risk, see Mark Kantor, Michael D. Nolan and Karl P. Sauvant, eds., Reports of Overseas Private Investment Corporation Determinations (New York: Oxford University Press, forthcoming 2011).
} 
acquire a portfolio of locational assets that provides them with better access to markets and resources of various kinds.

All in all, the national regulatory regime for FDI in host and home countries is today very favorable to foreign investors - probably more favorable than at any time in history. In particular, the manufacturing and natural resources ${ }^{11}$ sectors are largely open to such investment, although the liberalization process in the services sector has not gone equally far. In addition, countries actively seek to attract FDI, and home countries support the internationalization process of their firms through various means. One of these means is the establishment of a strong international investment law regime.

\section{B. The international regulatory framework}

As the principal capital exporting countries and homes to most MNEs, the developed countries have been the principal advocates and drivers of the establishment of a strong international investment law regime. Reflecting their interests, they sought rules that protect the investments made by their firms abroad and, beyond that, facilitate their operations in foreign markets, both in terms of market entry and managing their foreign affiliates on a day-to-day basis. At the same time, it was expected that such a regime would encourage the flow of investment to countries that were seen as lacking a strong rule of law in the investment area, i. e., especially the developing countries (and, later, the economies in transition).

As in the trade area, the construction of this investment regime began with bilateral treaties, in particular friendship, commerce and navigation (FCN) treaties and, since $1959,{ }^{12}$ bilateral investment treaties (BITs); by the end of 2009, there were about 2,750 BITs and some 250 free trade agreements with substantial investment chapters. ${ }^{13}$ The international investment law regime also consists of various regional, ${ }^{14}$ interregional $^{15}$ and partial multilateral ${ }^{16}$ agreements (collectively "international investment agreements" -- IIAs). In the absence of a comprehensive multilateral agreement on investment, the international investment law regime today consists

\footnotetext{
${ }^{11}$ In the natural resources sector, the involvement of MNEs often takes forms other than FDI (e.g. production sharing agreements, management contracts); however, in either case, control over the assets involved is typically in the hands of foreign investors.

${ }^{12}$ When the first BIT, between the Federal Republic of Germany and Pakistan, was concluded.

${ }^{13}$ UNCTAD 2010, op. cit., p. 81.

${ }^{14}$ Most important among them, the North American Free Trade Agreement, Chapter Eleven; at http://www.ustr.gov/trade-agreements/free-trade-agreements/north-american-free-trade-agreement-nafta

${ }^{15}$ Most important among them various OECD instruments, including OECD, Code of Liberalisation of Capital Movements (Paris: OECD, 1961); OECD, Declaration on International Investment and Multinational Enterprises (Paris: OECD, 1976), and the Energy Charter Treaty (ECT), Part III, Articles 1017, at: <www.encharter.org $>$.

${ }^{16}$ Especially the Agreement on Trade-related Investment Measures (TRIMs) and the General Agreement on Trade in Services (GATS), concluded in the framework of the WTO. The latter is particularly important as some two-thirds of FDI consists of services FDI. See also the Multilateral Investment Guarantee Agency, established in 1988 in the framework of The World Bank Group.
} 
therefore of a patchwork of rules, including voluntary instruments, ${ }^{17}$ that is multi-layered and multi-faceted.

Not surprisingly, furthermore, most IIAs reflect the interest and priorities of the developed countries as the traditional home countries of MNEs. In particular, they typically provide distinct protections for the post entry treatment of foreign investors, including fair and equitable treatment, full protection and security, treatment otherwise in accordance with the international minimum standard, and prompt, adequate and effective compensation in case of expropriation. Most modern investment agreements also provide investors a direct right to enforce these protections through investor-state arbitration. More recently, a growing number of these instruments also seek to facilitate the entry and operations of investors, most importantly by granting national treatment at the preestablishment phase and most-favored-nation treatment. ${ }^{18}$

In other words, the international investment law regime focuses largely on the rights of investors and the responsibilities of host countries, enforceable under international law. From that perspective, the regime today is open, stable and predictable, provides for transparent rules for the treatment of foreign investors and their foreign affiliates and can be enforced if need be. In fact, one could argue that the international investment law regime is stronger than the international trade regime, as it can be enforced directly by investors, as opposed to investors having to go through their governments in order to settle claims if and when they feel aggrieved. To quote Thomas Waelde:

Investment treaties $[\ldots]$ have built, indubitably, one of the most effective and truly legal regimes within the fragmented and mostly quite rudimentary institutional frameworks for the global economy. Comparable in terms of legal character and effectiveness to the WTO regime, the international investment regime is arguably more advanced, as it fully incorporates the most important and directly affected non-state actors. In a longer-term perspective, claimants (and their lawyers), who are essentially driven by private

\footnotetext{
${ }^{17}$ For example, the OECD "Guidelines for Multinational Enterprises" (which are part of the OECD Declaration, op. cit.).

${ }^{18}$ For a discussion of international investment law, see, for example, Jeswald W. Salacuse, The Law of Investment Treaties (New York: Oxford University Press, 2010); Peter Muchlinski, Federico Ortino and Christoph Schreuer, eds., The Oxford Handbook of International Investment Law (New York: Oxford University Press, 2008); Peter Muchlinski, Multinational Enterprises and the Law (New York: Oxford University Press, 2007) $2^{\text {nd }}$ ed.; Rudolf Dolzer and Christoph Schreuer, Principles of International Investment Law (New York: Oxford University Press, 2008); and August Reinisch, Recent Developments in International Investment Law (Paris: A. Pedone, 2009). For critical views, see, e.g., Gus van Harten, Investment Treaty Arbitration and Public Law (New York: Oxford University Press, 2007); José E. Alvarez, "The evolving foreign investment regime", American Society of International Law, 2008, at $<$ http://www.asil.org/ilpost/president/pres080229.html>; José E. Alvarez, "The once and future foreign investment regime”, in Mahnoush Arsanjani, Jacob Katz Cogan, Robert D. Sloane, and Siegfried Wiessner eds., Looking to the Future: Essays on International Law in Honor of W. Michael Reisman (forthcoming 2011); M. Sornarajah, The International Law of Foreign Investment (Cambridge: Cambridge University Press, 2004), $2^{\text {nd }}$ ed.; M. Sornarajah, "A coming crisis: expansionary trends in investment treaty arbitration”, in Karl P. Sauvant with Michael Chiswick-Patterson, eds., Appeals Mechanism in International Investment Disputes (New York: Oxford University Press, 2008), pp. 39-80; and M. Sornarajah, "Toward normlessness: The ravages and retreat of neo-liberalism in international investment law", in Karl P. Sauvant, ed., Yearbook on International Investment Law and Policy 2009/2010 (New York: Oxford University Press, 2010), ch. 16.
} 
interests, help ensure greater compliance and effectiveness for the treaties and their underlying objectives than can or is achieved by exclusively inter-state implementation procedures. It also goes beyond the prospective-remedy-only sanction available under the WTO. ${ }^{19}$

\section{Factors driving change}

These are the characteristics of the current international regulatory framework for FDI. However, a number of developments are underway that have an impact on the nature of this framework. Six are particularly noteworthy.

- A changing appreciation of the quality of FDI. While all governments continue to seek FDI as it can make a contribution to growth and development, a number of them are paying more attention to the quality of the investment they seek to attract, in terms of both the mode of entry of investment and the extent to which it has sustainable development characteristics.

As to the first consideration, relatively little attention was paid in the recent past to whether foreign investors entered a market through greenfield projects (i.e., the establishment of new production facilities) or through mergers and acquisitions $(\mathrm{M} \& A s)^{20}$ - both were seen as bringing the bundle of tangible and intangible assets associated with FDI that are important for development. ${ }^{21}$ In a number of countries, however, certain M\&As are increasingly regarded with reservation. The principal reasons include that M\&As merely represent a change in ownership and are often accompanied by restructuring (and hence frequently involve a reduction in employment if not the closing down of some production capacities), while greenfield investments create new productive capacity and hence employment. ${ }^{22}$ More importantly, when cross-border M\&As target firms in sensitive sectors (which can range from military hardware to critical infrastructure and sectors central to economic development) or national champions (in any industry), the political reaction can be particularly strong. ${ }^{23}$ This changing attitude toward M\&As is important as M\&As are the principal form of market entry for foreign investors in developed countries and an increasingly important form of market entry also in emerging markets.

19 Thomas W. Waelde, "Improving the mechanisms for treaty negotiation and investment disputes: competition and choice as the path to quality and legitimacy," in Karl P. Sauvant, ed., Yearbook on International Investment Law and Policy, 2008/2009 (New York: Oxford University Press, 2009), p. 514.

${ }^{20}$ Although some countries, like Australia and Canada, have since long screened large M\&As.

${ }^{21}$ See, UNCTAD, World Investment Report 2000: Cross-border Mergers and Acquisitions and Development (New York and Geneva: UNCTAD, 2000); Steven Globerman and Daniel Shapiro, "Modes of entry by Chinese firms in the United States: economic and political issues", in Karl P. Sauvant, ed., Investing in the United States: Is the US Ready for FDI from China? (Cheltenham: Edward Elgar, 2010), pp. 22-44.

${ }^{22}$ The advantages and disadvantages of M\&As vs. greenfield FDI are discussed, in great detail, in UNCTAD 2000, op. cit.; and Globerman and Shapiro, op. cit.

${ }^{23}$ See, e.g., the attempted acquisition of Unocal (United States) by CNOOC (China) or the rumored acquisition attempt of Danone (France) by PepsiCo (United States). 
As to the extent to which FDI has sustainable development characteristics, the objective of a number of governments is no longer just to obtain more such investment, but rather sustainable FDI. "Sustainable FDI" is defined here as FDI that contributes as much as possible to economic, social and environmental development and good governance (especially in terms of a mutually beneficial distribution of benefits associated with an investment ${ }^{24}$ ), while remaining profitable for the investing firms. While a number of governments have traditionally targeted investment that contributes particularly to economic development, the other dimensions of this concept have typically received less attention. ${ }^{25}$ This seems to be changing, especially as regards the social dimension of the concept but also the environmental one. ${ }^{26}$

The broader implication of this development is that some types of FDI are no longer being considered as equally welcome, i. e. that a number of governments are taking a more differentiated attitude toward the characteristics that incoming FDI takes ${ }^{27}$-- a fact (as will be discussed below) that is reflected in changes in the regulatory framework for foreign investment.

- The rise of emerging market MNEs. Adverse reactions to incoming M\&As can be even stronger when the acquirer is a firm headquartered in an emerging market. ${ }^{28}$ While traditionally the developed countries as a group have always been the most important host countries (absorbing by far more than half of all investment flows), the bulk of this investment came from other developed countries and was easily accepted. ${ }^{29}$ But with the rise of emerging market MNEs, ${ }^{30}$ this picture is

\footnotetext{
${ }^{24}$ This is particularly relevant in the natural resources sector, especially in light of swings in the prices of such resources and the distribution of the resulting revenues.

${ }^{25}$ Indicative of this are the results of a survey of investment promotion agencies undertaken in 2010 by the Vale Columbia Center on Sustainable International Investment regarding the extent to which these agencies pay attention to sustainable FDI; see Vale Columbia Center on Sustainable International Investment, "Investment promotion agencies and sustainable FDI: moving toward the fourth generation of investment promotion. Report of the findings of the Survey on Foreign Direct Investment and Sustainable

Development undertaken by the Vale Columbia Center on Sustainable International Investment (VCC) and the World Association of Investment Promotion Agencies (WAIPA) June 25, 2010", at

www.vcc.columbia.edu

${ }^{26}$ See in this context also UNCTAD 2010, op. cit.

${ }^{27}$ It may be indicative of this that arbitral tribunals have weighted in on the definition of "investment" for ICSID jurisdiction purposes, including be discussing whether contribution to development is an essential element; see e.g. MHS v Malaysia and the annulment decision.

${ }^{28}$ See, e.g., the discussions surrounding the acquisition of Arcelor by Mittal, Lenovo's acquisition of the PC division of IBM, and Tata's bid for Corus; see Karl P. Sauvant, "Driving and countervailing forces: a rebalancing of national FDI policies", in Sauvant, Investment Yearbook 2008/2009, op. cit., pp. 215-272.

${ }^{29}$ Developed countries continue to attract most FDI, although in 2009 emerging markets attracted almost half of the world's FDI inflows as the economies of these countries remained more resilient in the wake of the financial crisis and recession.

${ }^{30}$ See UNCTAD, World Investment Report 2006: FDI from Developing and Transition Economies. Implications for Development (Geneva: UNCTAD, 2009); Karl P. Sauvant with Kristin Mendoza and Irmak Ince, eds., The Rise of Transnational Corporations from Emerging Markets: Threat or Opportunity? (Cheltenham: Edward Elgar, 2008); and Sauvant and McAllister, with Maschek, op. cit. In fact, in 2008,
} 
changing. FDI flows from emerging markets have become important, having reached US\$ 351 billion in 2008, around seven times the average of world FDI outflows during the first half of the 1980s. On average, emerging markets accounted for 11 percent of global FDI outflows during 1995-2000; that share rose to 14 percent during 2003-2008. Even during the crisis year of 2008, when outflows from developed countries declined by almost 20 percent, those from emerging markets rose by 4 percent; in 2009, while outflows from developed countries plummeted by nearly half, those from emerging markets declined only by a bit more than one-fifth. As a result, the share of emerging markets in world FDI flows rose to 16 percent in 2008 and 25 percent in $2009 .{ }^{31}$ These aggregate data mirror, of course, the growth in foreign assets of MNEs headquartered in emerging markets (of which there are over $20,000^{32}$ ), and whose value has risen faster than the assets of their competitors headquartered in the industrialized world. In 2008 (the latest year for which these data are available), the foreign assets of the 100 largest MNEs from developing countries rose by 12 percent over the previous year, while the corresponding growth rate for the world's 100 biggest MNEs (overwhelmingly from industrialized countries) was only 1 percent. $^{33}$

This rise of MNEs headquartered in emerging markets changes the global FDI landscape. It remains to be seen how long it will take for the developed countries to accept these new competitors on equal terms (as investment treaties demand), or whether they will seek to impose new restrictions on entry, particularly when it takes the form of M\&As in high profile sectors. The integration of these new global players in the world FDI market is a difficult process, especially when they are different (or operate differently) from established MNEs.

One of these differences is that, in the case of a number of the new home countries, the most important players include state-controlled entities -- in particular state-owned enterprises and, increasingly, sovereign wealth funds. In the case of China (an extreme case), some 80-90 percent of outward FDI flows and stock are controlled by state-controlled enterprises. ${ }^{34}$ This aspect has given rise to special concerns (justified or not) about, for example, whether statecontrolled entities pursue non-commercial objectives when investing abroad, benefit from non-transparent favorable government treatment, or lack proper governance and accountability structures. As a result, some countries, such as

outward FDI flows from China were higher than the average of world FDI flows during the first half of the 1980s.

${ }^{31}$ Calculated on the basis of data from UNCTAD 2010, op. cit.

${ }^{32}$ Ibid, p. 17.

${ }^{33}$ Ibid., p. 18. To a certain extent, of course, this reflects the lower level of assets from which the former started as outward investors, compared with the latter.

${ }^{34}$ See Leonard K. Cheng and Zihui Ma, "China's outward FDI: Past and future”, July 2007, p. 15, at: http://www.nber.org/books_in_progress/china07/cwt07/cheng.pdf. (It should be noted that a number of developed country state-owned entities undertake FDI as well.) For a discussion of China's outward FDI, see Ken Davies, "Outward FDI from China and its policy context”, Columbia FDI Profiles, October 18, 2010, at www.vcc.columbia.edu. 
Australia, Canada, Germany, and the United States have become more cautious about sovereign FDI. ${ }^{35}$

The broader implication of the rise of emerging market MNEs is that a growing number of emerging markets - among them Brazil, China, India, and Russia (the BRICs), but also such countries as Chile, Mexico, Egypt, South Africa, Malaysia, the Republic of Korea, Singapore, and Thailand - see themselves no longer only as host countries but also as home countries, with implications for the international investment policies that they are pursuing. At the same time, host countries may exhibit some skepticism when it comes to the growing importance of emerging market MNEs, especially when these are state-controlled entities.

- Rising attention to national interest. Another implication of the rise of emerging market MNEs and the more differentiated attitude of governments to the form that incoming FDI takes is that considerations of "national interest" (and related concepts, such as "national security" and "essential security interests") have become more important in recent years, with these concepts not always clearly distinguishable from each other, and individual countries focusing on different aspects of them.

This is particularly true for a number of developed countries, but it also is beginning to extend to a number of emerging markets. For example, in the post9/11 United States, essential security concerns related to FDI have achieved greater saliency, as have concerns over foreign control over critical infrastructure. Such concerns are particularly evident when, in the case of M\&As, the prospective acquirer is headquartered in a country that may be considered a strategic competitor of the United States (as is China), or is based in a country whose political allegiances are viewed with some suspicion (e.g., some Islamic states) and/or is a state-controlled entity. For Western and Central European countries, "national security" concerns may reflect political fears of domination by investors from some countries (e.g., Russia and increasingly China) or concerns of threats to the "national interest" posed by foreign takeovers of national champions in key industries. For Russia, in turn, "national interest" or "security" concerns may emerge from investments related to the exploitation of natural resources or investment in firms controlling military technology. For some emerging markets, such as China, "national security" is being defined primarily in terms of economic development and hence focuses on strategic industries seen as crucial to continuing growth. And in yet other contexts, such as Argentina in the wake of its 2001-2002 economic crisis, "essential security" concerns have come to be associated with that nation's right to take emergency actions in the wake of domestic turmoil. ${ }^{36}$ What is common to all these approaches is that the underlying

\footnotetext{
${ }^{35}$ See the discussion below.

${ }^{36}$ On Argentina, see, e.g., José E. Alvarez and Kathryn Khamsi, "The Argentina crisis and foreign investors: A glimpse into the heart of the investment regime", in Sauvant, Investment Yearbook 2008/2009, op. cit., pp. 379-478. The lessons of Argentina have apparently been taken to heart by others; see, e.g., the latest Canadian Model BIT (permitting "prudential" measures with respect to the banking sector) and the
} 
security threat to the nation is intentionally left undefined. This is not surprising, as governments want to have the flexibility to define "national interest" and similar concepts in relation to specific circumstances, without being straightjacketed by pre-established definitions and commitments.

The broader implication of this development is that a number of developed countries that, in the past, sought strict international investment disciplines are now seeking greater flexibility and more policy space for themselves (an approach championed in the past principally by developing countries), in order to be able to pursue policies and take actions that they consider necessary - and enshrine this approach in their national regulatory frameworks and IIAs.

- The rise of investment disputes. Since the international investment law regime allows for investor-state disputes, it is not surprising that the number of cases in which investors feel aggrieved by actions taken by host countries is rising. (In fact, it is surprising that this has not occurred earlier and that there are not more such disputes, considering the number of MNEs and foreign affiliates that exist. ${ }^{37}$ ) The number of treaty-based international investment disputes has risen dramatically in recent years, with more than half of the 357 known arbitration cases having arisen between the beginning of 2004 and the end of 2009 (figure 1). Crucially, these disputes involve not only emerging markets as respondents (as was perhaps originally thought), but also developed countries, including the United States, ${ }^{38}$ as host countries, and they can lead to substantial awards against respondent countries. ${ }^{39}$

United States latest BIT (including a self-judging essential security clause). For discussion, see James Mendenhall, "The evolution of the essential security exception in U.S. trade and investment agreements," in Karl P. Sauvant, Lisa E. Sachs and Wouter P.F. Schmit Jongbloed, eds., Sovereign Investment: Concerns and Policy Reactions (New York: Oxford University Press, forthcoming 2011).

${ }^{37}$ Depending on the applicable IIA, foreign affiliates and, indeed, individual investors in affiliates, may be able to initiate disputes.

${ }^{38}$ By the end of 2009, at least 81 governments (49 of developing countries; 17 of developed countries, 15 of economies in transition) had been or were involved in treaty-based arbitrations; investors from developed countries had initiated the overwhelming number of claims. See ibid.

${ }^{39}$ See e.g., CME Czech Republic B.V. v. Czech Republic, (2003) UNCITRAL, at http://ita.law.uvic.ca/documents/CME-2003-Final_001.pdf, awarding CME Czech Republic B.V. US\$ $269,814,000$ in damages for breach of an investment treaty. 
Figure 1. Known investment treaty arbitrations (cumulative and newly instituted cases), 1989-2009 (number)

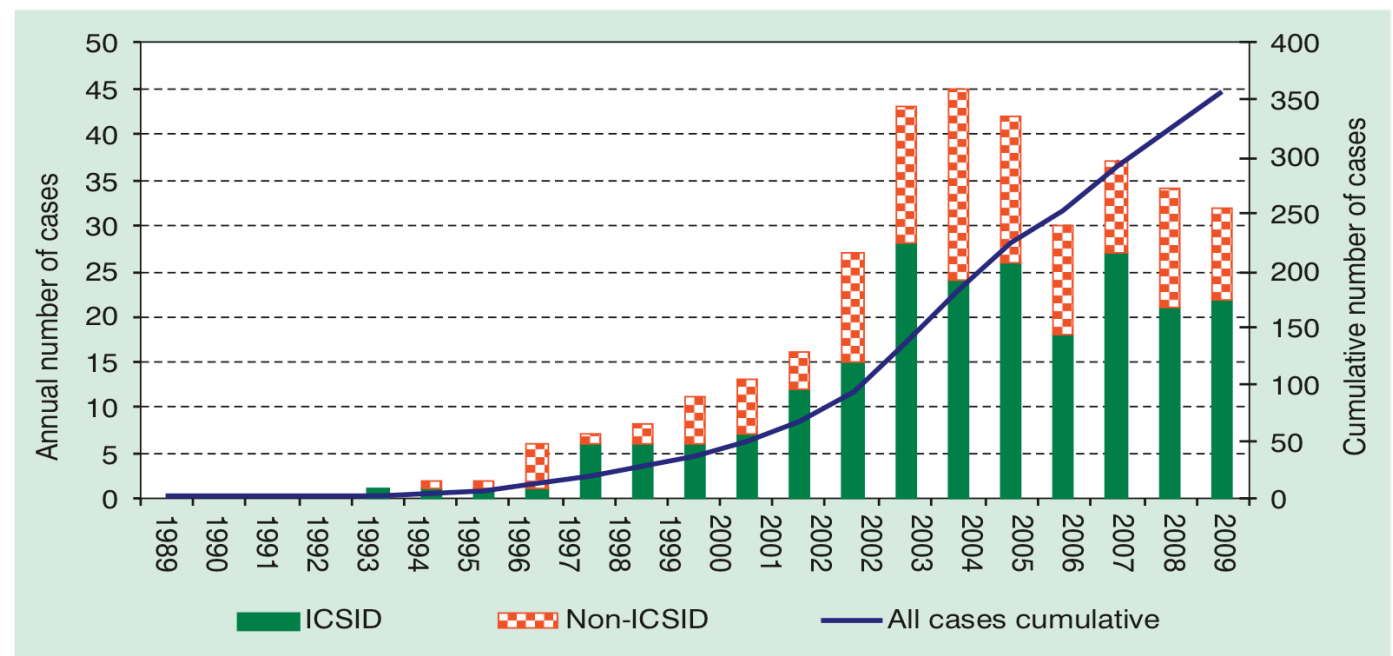

Source: UNCTAD, World Investment Report 2010: Investing in a Low-carbon Economy (Geneva: UNCTAD, 2010), p. 84.

Both the number of disputes as well as the types of claims being made in them are giving rise to second thoughts on the part of IIA signatories, many of which did not expect the types of challenges to government regulation or even judicial actions that are emerging in the course of treaty-based arbitrations. Complaints that state parties to investment treaties are increasingly put on the defensive in investor-state claims and that, even when states win the underlying disputes, the threat of litigation produces an untoward regulatory chill, have become a common refrain among a number of non-governmental organizations, including in developed countries. There is also a perception that, although the goal of the investment regime was to promote harmonious and predictable rules, investorstate arbitral decisions have not led to consistent international investment law, even producing inconsistent rulings arising under strikingly similar facts. ${ }^{40}$ The high profile of some investor-state decisions and the adverse attention drawn to a number of them that implicate policy questions have also undermined the contention that international arbitrations will successfully depoliticize such matters.

The broader implication of these developments is that governments of developed countries, led by the Unite States, are becoming more conscious of their status as host countries ${ }^{41}$ and, in that position, potentially subject to claims against them.

\footnotetext{
${ }^{40}$ For a discussion of Argentina cases, see Alvarez and Khamsi, op. cit.

${ }^{41}$ As is suggested by the United States' divisive debates over the content of its United States' Model BIT. See "Report of the Subcommittee on Investment of the Advisory Committee on International Economic
} 
As a result, governments are becoming more skeptical of their decisions to delegate the right to initiate investment disputes to private third party beneficiaries and more concerned about the consequences of such delegation on their continuing right to regulate in the public interest. This, in turn, further influences the attitude countries take to the content of international investment obligations.

- Doubt about whether IIAs lead to more FDI. There are also growing questions as to whether one of the principal purposes of IIAs is being achieved, namely the goal of increasing FDI flows, especially to emerging markets, with the help of investment treaties. Empirical research to date has not established a clear relationship between such agreements and FDI flows. ${ }^{42}$ This is not surprising, as factors relating to host countries' economies (especially market size and growth, the quality of the infrastructure, skills, innovatory capacity) are by far the most important FDI determinants, and it is therefore difficult to isolate any IIA-specific effects. ${ }^{43}$ It is also not surprising given the fact that most IIAs are premised on the assumption that a good regulatory framework (as established by IIAs) is sufficient to encourage MNEs to go forward with their investments; this ignores the fact that, at best, the (national and international) regulatory framework can only be enabling - but unless the economic determinants allow for profitable investments, it is very unlikely that FDI will take place. ${ }^{44}$ Moreover, IIAs, as a rule, do not provide for active measures by home country to encourage their firms to invest abroad (and especially in emerging markets or at least in the least developed countries), or to help institutions in host countries to acquire the capacity to attract foreign investors. In fact, although IIAs presume that the protection of investment and the removal of governmental barriers to free capital flows would enhance such flows, the treaties themselves were not necessarily intended to promote such

Policy regarding the Model Bilateral Investment Treaty", at

http://www.state.gov/e/eeb/ris/othr/2009/131098.htm>.

42 The most important studies are contained in Karl P. Sauvant and Lisa E. Sachs, eds., The Effect of Treaties on Foreign Direct Investment: Bilateral Investment Treaties, Double Taxation Treaties and Investment Flows (New York: Oxford University Press, 2009). As a recent study observed: “... the literature on BITs is stalemated on whether they actually increase FDI..." (see Jennifer L. Tobin and Marc L. Busch, "A bit is better than a lot: bilateral investment treaties and preferential trade agreements", World Politics, vol. 62 (2010), pp. 1-42). The same study observed however also that BITs might make free trade agreements more likely and, in this manner, indirectly influence FDI flows. Perhaps one of the reasons for this finding is that corporate counsels seem to be relatively unfamiliar about the existence of BITs - at least this is the result of a survey of United States MNEs; see Jason Webb Yackee, "How much do U.S. corporations know (and care) about bilateral investment treaties? Some hints from new survey evidence", Columbia FDI Perspective (forthcoming).

${ }^{43}$ For a discussion of the FDI determinants, see UNCTAD, World Investment Report 1998: Trends and Determinants (Geneva: UNCTAD, 1998), chapter IV; and Dunning and Lundan, op. cit. Some countries, like Brazil, attracts considerable amounts of FDI, even though it has not ratified any of the BITs it had negotiated.

${ }^{44}$ Conversely, even when the regulatory framework is not very good, FDI will take place if profitable investment opportunities exist. For example, investments in the mining sector took place in the Congo even during the country's civil war. 
This chapter is $($ Emerald Group Publishing and permission has been granted for this version to appear here

(http://www.vcc.columbia.edu). Emerald does not grant permission for this chapter to be further copied/distributed or hosted

elsewhere without the express permission from Emerald Group Publishing Limited.

flows, at least as far as some capital exporting countries are concerned. ${ }^{45}$ They were, at best, signaling devices to encourage investors to seek out those host countries with a favorable investment climate.

The broader implication of this development is that, if IIAs do not necessarily lead to more investment flows, governments may become less inclined to make investor-protection and liberalization commitments - or even conclude such agreements in the first place.

- Doubts about whether outward FDI is a good thing for home countries. As mentioned earlier, all developed countries and a growing number of developing countries facilitate or even support the outward investment of their firms. However, doubts have occasionally arisen in a number of developed countries as to whether outward FDI is indeed beneficial for home countries. ${ }^{46}$ Trade unions in particular are concerned about the export of jobs seen as being associated with outward FDI; and such concerns are particularly potent during times of economic crisis and high levels of unemployment. While a number of studies have shown that outward FDI is beneficial to home countries, at least on balance and for developed home countries, ${ }^{47}$ the public debate in the United States and Europe at times assumes differently. Most recently, for example, offshoring has led to calls in the United States to restrict this kind of activity. ${ }^{48}$ There have also been threats by some in the United States Congress to block the approval of BITs and free trade agreements (or even to withdraw from existing agreements, including the North American Free Trade Agreement (NAFTA)). ${ }^{49}$ In Western Europe, outward

\footnotetext{
45 As Vandevelde observed for the United States: "When the BIT program was inaugurated in the Carter Administration, the United States had seen the BITs as a means of building a body of state practice consistent with its view of customary international law while protecting existing stocks of investment. In part because of concerns that labor otherwise would oppose the agreements, United States BIT negotiators initially had made clear not only to potential United States BIT partners but to Congress as well that there was no evidence that BITs would lead to increased outward investment flows. By the early 1990s, however, the promotion of democracy and market economics in the transitional economies was a major foreign policy objective and BITs were regarded as a means of promoting outward investment"; Kenneth J. Vandevelde, U.S. International Investment Agreements (New York: Oxford University Press, 2009), p. 45. As this observation suggests, the promotion of FDI was not a goal when the United States' BITs program began in the 1970s. However, over time, the argumentation changed, and eventually BITs were justified in the United States as a means of investment promotion.

${ }^{46}$ See e.g., Cynthia O'Murchu and Jan Cienski, "Twinings to move tea plant to Poland", Financial Times, November 9, 2010, who report that the move "has drawn sharp criticism from both workers and members of the European parliament".

${ }^{47}$ See e.g., Moran, forthcoming, Section VII; Steven Globerman and Daniel M. Shapiro, "Outward FDI and the economic performance of emerging markets”, in Sauvant, with Mendoza and Ince, op. cit., pp. 229-271; and Hans Visser, "Outward foreign direct investment: is it a good thing?" in G. Meijer, W.J.M. Heijman, J.A.C. van Ophem, and B.H.J. Verstegen, eds., Heterodox Views on Economics and the Economy of the Global Society (Wageningen: Wageningen Academic Publishers, 2006), pp. 343-358.

${ }^{48} \mathrm{Se}$, e.g. James Politi, "Bill on overseas jobs raises hopes and fears in US", Financial Times, September 27, 2010; and William S. Cohen, "Obama and the politics of outsourcing", Wall Street Journal, October 12, 2010.

${ }^{49}$ See, e.g., Doug Palmer, "U.S. lawmakers launch push to repeal NAFTA", Washington Post, March 4, 2010, at <http://www.reuters.com/article/dUSTRE6233MS20100301>.
} 
investment in general has occasionally come under fire in some countries, under the heading of "delocalisation"; in at least in one instance, the President of one country is reported to have linked the provision of aid to some firms to these firms repatriating from abroad some production facilities, or keeping the production of certain products at home. ${ }^{50}$

In the case of emerging markets that have become important outward investors, doubts of this kind do not seem to have become prominent so far, although it would not be surprising if they should become at one point in the future. After all, most emerging markets do not have all the production capacities they need to provide their citizens with an advanced standard of living. Hence, investment abroad to create production capacities there could easily lead, at one point, to a backlash against outward FDI in emerging markets, even though such investment is in the interest of the firms involved as they need (as mentioned earlier) a portfolio of locational assets to remain internationally competitive.

The broader implication of this situation is that there is a tension between the objective of MNEs to maximize their global (or at least regional ${ }^{51}$ ) competitiveness, on the one hand, and the objective of governments to maximize the performance of their territorially bound economies, on the other hand. The establishment of regulatory frameworks for FDI in light of a sometimes somewhat fragile consensus about the benefits of outward FDI for home countries needs to take this tension into account.

These are all developments that, in various ways, influence national and international FDI rule making. They show that governments look at FDI with fresh eyes as regards the costs and benefits that it brings to them, not only in terms of its contribution to economic development, but also in terms of serving broader national objectives. The following section shows that this revaluation of at least certain types of FDI is beginning to find its expression in national and international regulatory frameworks and their implementation.

\section{The changing regulatory regime for FDI}

As a result of these developments, a number of countries have introduced changes or "clarifications" in their national regulatory regime that provide them with more leeway to deal with incoming investments, especially when these are undertaken by statecontrolled entities and are taking the form of M\&As. Significantly, the erstwhile strongest supporter of open national rules and a strong international investment law regime is leading this change. ${ }^{52}$ In the United States, the Foreign Investment and National Security Act (FINSA) of 2007 and its subsequent implementing regulations strengthened the role of the Committee on Foreign Investment in the United States (CFIUS) as a

\footnotetext{
${ }^{50}$ See, e.g., Ben Hall, "France to rein in state-backed groups", Financial Times, August 4, 2010.

${ }^{51}$ As Alan Rugman shows, most MNEs are primarily regional in their operations; see his The Regional Multinationals (Cambridge, UK: Cambridge University Press, 2005).

${ }^{52}$ The developments discussed in this paragraph are documented in Sauvant, "Driving and countervailing forces", op. cit., and are therefore not individually referenced here.
} 
screening mechanism for incoming FDI under national security aspects. CFIUS has the authority to review and investigate covered transactions and to negotiate, impose and enforce conditions necessary to mitigate any threat to national security presented by any such transaction. A transaction will be investigated if, among other things, it involves a foreign government-controlled entity and if it would result in control of any critical infrastructure and could impair national security. Neither "national security" nor "critical infrastructure" is defined precisely. Germany, too, changed its law on foreign investment in 2009, to allow the government to review certain takeovers by firms from outside the European Economic Area. Australia and Canada tightened or "clarified" their regulations in 2008 and 2009, respectively, emphasizing that M\&As by foreign state-controlled entities will receive special attention. France identified at the end of 2005 a number of sectors in which FDI is restricted. The Commission of the European Community, for its part, initiated in 2008 a process of consultations, with a view toward arriving at a common approach toward SWFs. The OECD, too, undertook a similar process and arrived in 2008 at "Guidelines for Recipient Country Investment Policies Related to National Security".53 Outside the OECD area, Russia adopted in 2008 a law that established procedures for foreign investments in companies of strategic importance for national defense and security, and China (which always had a list of encouraged, restricted and prohibited projects for foreign investors) introduced during 2006-2008 a review process in light of national economic security considerations. Finally, the IMF decided in 2007, prodded by developed countries, to identify best practices for SWFs; as a result, and with the participation of representatives of SWFs, "Generally Accepted Principles and Practices" (the "Santiago Principles") were adopted in 2008, reflecting "appropriate governance and accountability arrangements as well as the conduct of investment practices by SWFs on a prudent and sound basis". 55

As can be seen from the dates of these various initiatives, the great majority of them were initiated before the world financial crisis and recession struck in late 2008. In fact, during the crisis, state-controlled entities were often regarded as "white knights" that bailed out in particular financial institutions in distress, and countries heeded the calls of the Group of 20 to refrain from FDI protectionism. ${ }^{56}$ However, once countries have emerged fully from the crisis while, on the other hand, SWFs and state-owned enterprises amass even higher foreign exchange earnings and seek to invest them in equities, ${ }^{57}$ it is likely that the fears related to them will reassert themselves and will be reflected in national and international regulatory instruments.

\footnotetext{
${ }^{53}$ See OECD, "Guidelines for Recipient Country Investment Policies relating to National Security", Recommendation adopted by the OECD Council on 25 May 2009), at http://www.oecd.org/dataoecd/11/35/43384486.pdf.

${ }^{54}$ See International Working Group of Sovereign Wealth Funds, "Sovereign Wealth Funds: Generally Accepted Principles and Practices, 'Santiago Principles"” (2008), at $<$ http://www.iwgswf.org/pubs/gapplist.htm>.

${ }^{55}$ Ibid, p. 4.

${ }^{56}$ G8 leaders' declaration, "Responsible Leadership for a Sustainable Future”, L'Aquila, G8 Summit 2009 , at: http://www.g8italia2009.it/static/G8_Allegato/G8_Declaration_08_07_09_final,0.pdf.

${ }^{57}$ SWFs are estimated to control about US\$ 4 trillion dollars (Sovereign Wealth Fund Institute, October 2010, at: http://www.swfinstitute.org), an amount that is estimated to go up to US\$ 12 trillion by 2015, given certain assumptions; see Stephen Jen, "How big could Sovereign Wealth funds be by 2015?", Morgan Stanley Global Economic Forum, May 4, 2007, at: www.morganstanley.com.
} 
More broadly, during the crisis and recession, countries sought more capital to help them emerge from the recession; in other words, inward FDI was particularly welcome. At the same time, as long as unemployment remains high in key home countries, the question of offshoring of services is likely to remain a topic for discussion; in other words, outward FDI could potentially be restricted or at least discouraged. However, once countries have emerged from the recession and once unemployment has declined, some of the other considerations discussed earlier as they relate to the cost/benefit calculation of governments regarding FDI are likely to reassert themselves, especially when it comes to M\&As targeting national champions or other enterprises considered important to the national economy (e.g. in natural resources ${ }^{58}$ ). For the same reason, it may also well be that further liberalization, especially in sensitive services sectors, may slow down.

Partly as a result of legislative changes, countries -- especially (but not only) developed ones, but including all those mentioned earlier -- have also strengthened their capacity to screen FDI projects, typically focused on M\&As. In the case of the United States, for example, the number of filings with the Committee on Foreign Investment in the United States rose, between 2001 and 2008, from 55 to 155, and the number of investigations grew from 1 to 23 (figure 2).

Figure 2. CFIUS filings and investigations, $2001-2009$

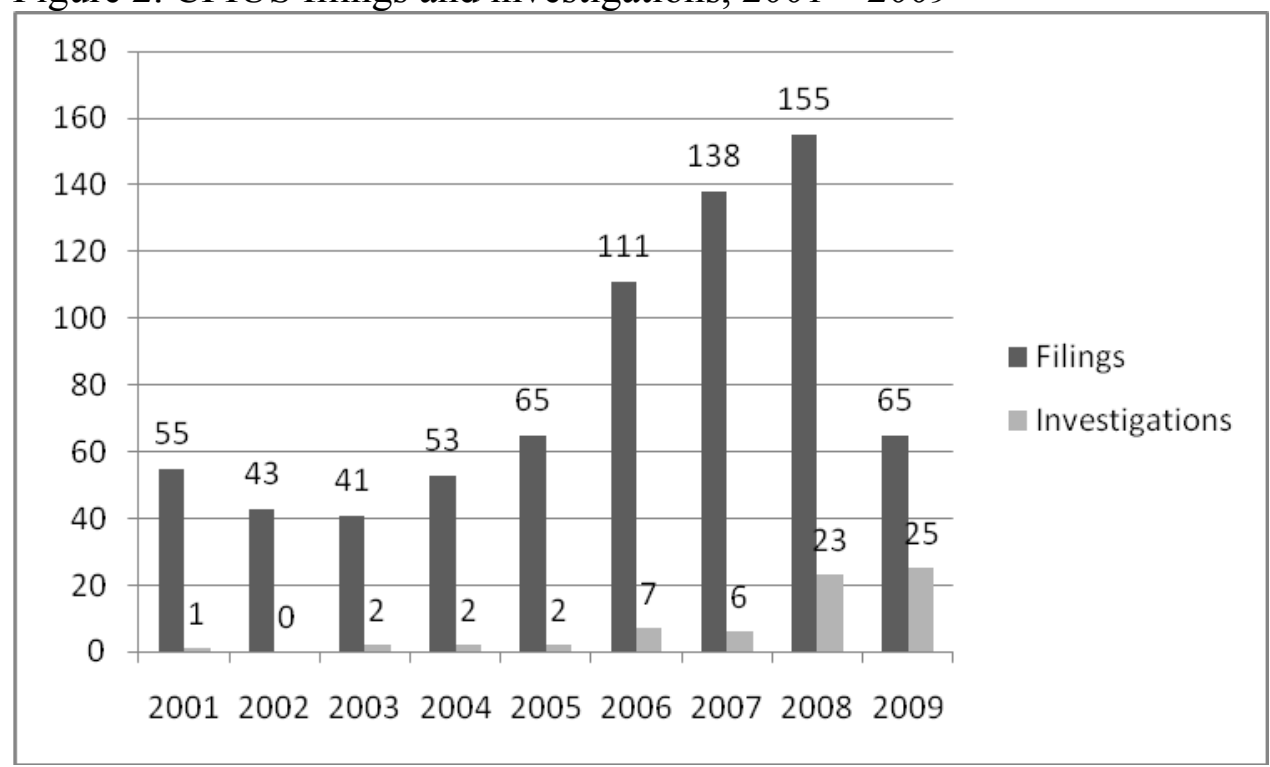

Source: US Treasury Department, available at: www.ustreas.gov.

In 2008, 15 percent of CFIUS filings led to investigations. While the number of

\footnotetext{
${ }^{58}$ See, e. g., the preliminary decision of the Government of Canada to block the acquisition of PotashCorp (Canada) by BHP Billiton (Australia) in November 2010; see Alan Beattie and Bernard Simon, "Race for resources tests trade openness", Financial Times, November 6/7, 2010.
} 
notifications declined in 2009 to $65,{ }^{59}$ the number of investigations rose to 25 , representing about 40 percent of the filings - a substantial increase. It should be noted that these types of examinations of M\&As, in the United States and elsewhere, are typically not subject to judicial review but rather take place within the "black box" of discussions within the relevant government agencies, thereby reducing the transparency of the decision-making process and regulatory framework.

The change toward a more circumscribed treatment of foreign investors and more policy space for governments in light of a changed cost/benefit calculation on the part of governments is also beginning to be reflected in international investment agreements and, with that, is bound to influence the international investment law regime in general. In particular, leading countries such as Canada and the United States are now concluding IIAs with more limited protections for investors and greater scope for governmental action, including through broad exceptions. Changes to United States' IIAs include a narrower definition of fair and equitable treatment and reduced scope for investors to claim that they have been the victims of a regulatory taking. ${ }^{60}$ Canada has opted for an ample list of general exceptions from IIA protections inspired by those contained in Article XX of the General Agreement on Tariffs and Trade (GATT). ${ }^{61}$ These changes lessen the risk of unpredictably broad interpretations of investment protections by investor-state arbitrators. Most importantly, some countries, such as the United States, are turning to a "self-judging" essential security exception intended to oust certain disputes, at the option of the respondent state, from investor-state arbitration altogether. Given the fact that "essential security" is left undefined, such an exception from arbitrability potentially undermines the entire edifice of international investment law.

More generally, the countries worldwide that introduced during 2006-2007 at least one change making their investment climate less welcoming for foreign investors accounted for 40 percent of world FDI flows. ${ }^{62}$

While the policy changes in China and Russia concerned all foreign direct investment, those in most developed countries paid special heed to state-controlled entities as a class of investors, introducing differential treatment for them. The latter also applies to the initiatives by the European Commission, the OECD and the IMF, even if they remain voluntary. They are justified largely on the basis of national security considerations, in particular the fear that the FDI activities of state-controlled entities, especially in the case of M\&As, are driven not so much by commercial but rather by

\footnotetext{
${ }^{59}$ The decline may have been the result of the lower number of cross-border M\&As into the United States on account of the crisis and the decline of FDI inflows; that number fell from 1,297 in 2007 to 1,117 in 2008, to 710 in 2009, and 293 during January to May 2010; in terms of value, cross-border M\&As into the United States declined from US\$ 165 billion in 2007 to US\$ 40 billion in 2009 (see http://www.unctad.org/Templates/Page.asp?intItemID=5545\&lang=1); FDI flows into the United States declined from US\$ 324 billion in 2008 to US\$ 130 billion in 2009 (UNCTAD 2010, op. cit., p.167). It is not known how many cross-border M\&As that were intended or initiated but did not go forward because of the new regulatory framework in the United States.

${ }^{60}$ United States' Model BIT 2004, at: http://www.state.gov/documents/organization/117601.pdf.

${ }^{61}$ Canadian Model BIT 2004, at: <http://www.international.gc.ca/trade-agreements-accordscommerciaux/assets/pdfs/2004-FIPA-model-en.pdf>; General Agreement on Tariffs and Trade, http://www.wto.org/english/docs_e/legal_e/06-gatt_e.htm.

${ }^{62}$ Sauvant, "Driving and countervailing forces", op. cit., p. 240.
} 
political considerations. This may well be the case, but to date there is no systematic evidence to show that (be it for sovereign wealth funds and state-owned enterprises from emerging markets or developed countries), i. e. it is difficult to show that a substantial number of investment decisions would not have been undertaken by private firms in the same situation on the basis of commercial considerations alone.

In any event, the changes in the national and international regulatory frameworks for FDI go beyond specific considerations regarding state-controlled entities. They show that governments are searching for a new balance between the rights and responsibilities of governments and foreign investors at both the national and international levels, driven by the various developments discussed earlier.

Among these developments, probably none is more important than the blurring of the traditional distinction between developed "capital exporting" and developing "capital importing" countries. To be sure, developed countries have always been (and still remain) the principal host countries for FDI - but this FDI originated overwhelmingly in other developed countries; any issues that arose in connection with this investment could be discussed and settled in the framework of the OECD, on the basis of the instruments of that Organisation. What is new for developed countries is the rising influx of FDI from emerging markets. While emerging markets continue to remain primarily host countries, ${ }^{63}$ the rise of their own MNEs is likely to bear on their perspective on the international investment law regime as governments in a growing number of emerging markets are now paying more attention to their status as capital exporters, as their firms, some of which have become major international players, ${ }^{64}$ invest abroad.

Both developed countries and emerging markets now need to balance their positions as home and host countries, and hence their objectives: as home countries, they seek a strong international regulatory regime that protects foreign investors and facilitates their operations; as host countries, they seek an international regulatory regime that leaves them sufficient policy space for their right to regulate in the public interest. It is a tension that finds its expression in the negotiation of IIAs.

This tension is exemplified by changes in the model BITs and actual investment treaties of the United States and China, as both are today simultaneously the leading capital exporting (home) and capital importing (host) countries among, respectively, the developed countries and the emerging markets. ${ }^{65}$ United States IIAs began as very strong investor protection devices, as laid out in their clearest form in the 1984 US model BIT and the IIAs based on it. ${ }^{66}$ Once the United States became a respondent in treaty-based

\footnotetext{
${ }^{63}$ The inward FDI flows of emerging markets were roughly an average of US\$ 650 billion during 20072009, while their outward flows during the same period were an average of US\$ 310 billion; the inward FDI stock of emerging markets was US\$ 5.4 trillion in 2009, compared with an outward stock of US\$ 3 trillion; see UNCTAD 2010, op. cit., annex tables 1 and 2.

${ }^{64}$ The four BRICs (Brazil, Russia, India, China) alone accounted for more than a third of FDI outflows from emerging markets during 2007-2009; see ibid. For rankings of the largest MNEs based in the BRICs, see www.vcc.columbia.edu.

${ }^{65}$ See, e.g., Jose E. Alvarez, “Contemporary foreign investment law: An 'Empire of Law' or the: 'Law of Empire'?", Alabama Law Review, no. 60 (2009), pp. 943-975

66 See Alvarez, "The evolving foreign investment regime," op. cit.; and Kenneth J. Vandevelde, "A comparison of the 2004 and 1994 U.S. Model BITs: Rebalancing investor and host country interests", in
} 
international investment claims after the conclusion of NAFTA, it gradually circumscribed or even dropped various protections in order to maintain the regulatory space it needed to pursue its own policy objectives and limit the possibility that claims could be brought against it; this evolution is captured in the 2004 United States model BIT and the IIAs based on it. ${ }^{67}$ Chinese IIAs, for their part, began as relatively weak investor protection devices, but then moved in the direction of the strongly investorprotective United States model of 1984 (as Chinese investors invested in significant numbers and amounts abroad) -- only to move, in its latest BITs, toward the United States position of less expansive formulations on such a key protection standard as fair and equitable treatment. ${ }^{68}$

The extent to which two leading capital exporters and importers of the world, China and the United States, are now groping to find the right balance that reflects their positions as both host and home countries, are concluding separate investment agreements with increasingly similar provisions and are even negotiating one as between themselves, gives rise to the hope that, eventually, and despite the proliferation of IIAs, the "spaghetti bowl" of agreements will eventually coalesce around agreed terms that respect the need of investors for the rule of law and fairness of process and the right of governments to regulate in the public interest. Perhaps this will occur in the framework of a Multilateral Agreement on Investment that enshrines a new balance of the rights and responsibilities of the various stakeholders in the regime and promotes sustainable FDI, and, thereby, as Aharoni put it, attempts to "determine the optimum balance between the incentives necessary to attract FDI and the regulation required to defend the pubic interest". ${ }^{69}$

Sauvant, Investment Yearbook 2008-2009, op. cit., pp. 283-316. The full text of 1984 United States Model BIT can be found in Kenneth Vandevelde, United States Investment Treaties Policy and Practice (Boston: Kluwer, 1992).

${ }^{67}$ See, Alvarez, “The evolving foreign investment regime," op. cit., and Vandevelde, “A comparison”, op. cit.

${ }_{68}^{68}$ Alvarez, “The evolving foreign investment regime", op. cit., and Vandevelde, op. cit.

${ }^{69}$ Aharoni, op. cit., p. 56. 